\title{
Determinan Audit Report Lag dan Peran Auditor Spesialisasi Industri Sebagai Pemoderasi Pada Perusahaan Badan Usaha Milik Negara
}

\author{
Yudhi Prasetiyo ${ }^{1,}$ Nurmala Ahmar ${ }^{2}$, M. Ardiansyah Syam ${ }^{3}$ \\ 1,2,3 Universitas Pansacila, Jakarta, Indonesia
}

\section{INFO ARTIKEL JEL Classification :}

M42, D21

\section{Keywords :}

Audit report lag, kap size, profit ability, company size, audit tenure, investment opportunity set, industry specialist auditors

\begin{abstract}
This study aimed to examine the effect of KAP size, profitability, company size, audit tenure, and investment opportunity set on audit report lag with auditor industry specialization as a moderating variable. This research uses a quantitative method with a descriptive approach. The population in this study is the BUMN Go Public Company listed on the Indonesia Stock Exchange (IDX) in 2014-2018. The sampling technique uses purposive sampling method. The sample in this study were only companies that passed the sample criteria of 100 companies. The data were analyzed uses moderate regression analysis (MRA). The results of this study found that audit tenure had a positive and significant effect on audit report lag, profitability and firm size had a negative effect and significant on audit report lag, and the size of KAP and investment opportunity set had no effect on audit report lag. Then the moderation regression analysis results of this study found that industrial specialization auditors moderate positive toward profitability and firm size against to audit report lag, industrial specialization auditors moderate toward negative audit tenure to audit report lag. Where as industry specialization auditors don't moderate the KAP size and investment opportunity set of audit report lag.
\end{abstract}

\begin{abstract}
ABSTRAK
Penelitian ini bertujuan untuk menguji pengaruh ukuran KAP, profitabilitas, ukuran perusahaan, audit tenur, dan investment opportunity set terhadap audit report lag dengan auditor spesialisasi industri sebagai variabel moderating. Penelitian ini menggunakan metode kuantitatif dengan pendekatan deskriptif. Populasi dalam penelitian ini adalah Perusahaan BUMN Go Public yang terdaftar di Bursa Efek Indonesia (BEI) tahun 2014-2018. Teknik pengambilan sampel menggunakan metode purposive sampling. Sampel di dalam penelitian ini adalah hanya perusahaan-perusahaan yang lolos mengikuti kriteria sampel sebanyak 100 perusahaan. Analisis data menggunakan moderate regression analys (MRA). Hasil penelitian menunjukkan bahwa audit tenur berpengaruh positif dan signifikan terhadap audit report lag, profitabilitas dan ukuran perusahaan berpengaruh negative dan siginifikan terhadap audit report lag serta ukuran KAP dan investment opportunity set tidak berpengaruh terhadap audit report lag. Kemudian hasil regresi moderasi analisis menunjukan bahwa auditor spesialisasi industri memodersi semu kearah positif
\end{abstract}


profitabilitas dan ukuran perusahaan terhadap audit report lag, auditor spesialisasi industri memodersi semu kearah negative audit tenur terhadap audit report lag Sedangkan auditor spesialisasi industri tidak memodersi ukuran KAP dan investment opportunity set terhadap audit report lag.

\section{Pendahuluan}

Keterlambatan waktu laporan keuangan auditan yang disampaikan oleh auditor kepada perusahaan dapat mempengaruhi kualitas informasi dari laporan tersebut karena panjangnya waktu tunda audit menunjukan bahwa informasi yang diberikan tidak out of date dan informasi yang lama menunjukan bahwa kualitas dari laporan keuangan tersebut buruk. Lamanya proses penyelesaian audit dapat mempengaruhi keterlambatan audit dalam menyampaikan laporan keuangan auditan kepada publik sehingga dapat berdampak buruk terhadap reaksi pasar (Hesti, 2011) serta menyebabkan ketidakpastian dalam hal pengambilan keputusan ekonomi khususnya bagi pengguna laporan keuangan.

Audit report lag merupakan rentang waktu penyelesaian pelaksanaan audit laporan keuangan tahunan yaitu sejak tanggal tutup tahun buku perusahaan sampai dengan tanggal yang tertera pada laporan auditor independen. Audit report lag merupakan aspek penting dalam menjaga relevansi dari informasi yang dibutuhan para pengguna laporan keuangan. Tujuan laporan keuangan menurut (IAI, 2009) adalah menyediakan informasi yang menyangkut posisi keuangan suatu perusahaan yang bermanfaat bagi sejumlah besar pengguna dalam pengambilan keputusan ekonomi. Proses audit ditujukan untuk meningkatkan nilai dari sebuah pernyataan manajemen sehingga apa yang dilaporkan dalam laporaan keuangan perusahaan dapat dipercaya dan disajikan secara wajar. Untuk mengidentifikasi audit lag dalam proses audit suatu laporan keuangan selayaknya tidak hanya meilhat dari sisi internal perusahaan selaku klien audit namun juga dari sisi auditor selaku partner audit.

Pentingnya mengendalikan audit report lag juga telah diuji dalam penelitian (Bae \& Woo, 2015)yang menemukan bahwa Audit Report Lag dan discretionsary terhadap kesalahan peramalan analisis perusahaan baik pada peramalan 6 bulan, 3 bulan, maupun 1 bulan sebelum tutup buku perusahaan di Korea. Hasil tersebut mengindikasikan bahwa audit report dapat menyebabkan interpretasi yang salah terhadap pengumuman laba akuntansi suatu perusahaan. Untuk menghindari interpretasi yang salah maka diperlukan peran auditor dalam laporan keuangan perusahaan. Namun audit itu sendiri jangan sampai menjadi alasan penundaan pelaporan keuangan sehingga prosesnya harus optimal sesuai dengan alokasi waktu yang efisien.

Tentang Penyampaian Laporan Keuangan Berkala Emiten atau Perusahaan Publik, OJK mewajibkan setiap perusahaan publik yang terdaftar di pasar modal wajib menyampaikan laporan keuangan tahunan yang telah di audit oleh auditor independen kepada OJK dan diumumkan kepada masyarakat paling lambat pada akhir bulan keempat setelah tahun buku berakhir hal ini diatur dalam peraturan Keputusan Ketua Badan Pengawas Pasar Modal dan Lembaga Keuangan Nomor: Kep/346/BL/2011 tentang Penyampaian Laporan Keuangan Berkala Emiten atau Perusahaan Publik kemudian di sempurnakan kembali dengan keluarnya Peraturan OJK Nomor: $\quad$ 7/POJK.04/2018 tentang Penyampaian Laporan Melalui Sistem Pelaporan Elektronik Emiten Atau Perusahaan Publik.

Perusahaan yang tidak menyampaikan laporan keuangan sampai batas waktu yang ditentukan akan dikenakan sanksi administratif sesuai dengan Peraturan Pemerintah No. 45 Tahun 1995 tentang Penyelenggaraan Kegiatan di Bidang Pasar Modal Bab XII pasal 63 huruf e yang menyatakan bahwa bagi setiap perusahaan publik yang terdaftar di Bursa Efek Indonesia (BEI) akan dikenakan sanksi denda $\mathrm{Rp}$ 1.000.000 (satu juta rupiah) atas setiap hari keterlambatan penyampaian laporan keuangan dengan jumlah keseluruhan denda paling banyak $\mathrm{Rp} 500.000 .000$ (lima ratus juta rupiah). Penetapan dari sanksi administrasi 
tersebut sudah selayaknya membuat perusahaan sadar tentang pentingnya penyampaian laporan keuangan yang telah diaudit secara tepat waktu.

Berdasarkan data yang diperoleh dari Bursa Efek Indonesia, pada tahun 2018 terdapat 64 perusahaan Go Public di BEI terlambat menyampaikan laporan keuangan auditan , pada tahun 2017 sebanyak 70 perusahaan terlambat menyampaikan laporan keuangan auditan, pada tahun 2016 terdapat 35 perusahaan yang terlambat menyampaikan laporan keuangan auditan, pada tahun 2015 terdapat 63 perusahaan terlambat menyampaikan laporan keuangan auditan dan pada tahun 2014 terdapat 52 perusahaan terlambat menayampaikan laporan keuangan auditan. Jumlah perusahaan yang terlambat menyampaikan laporan keuangannya selalu mengalami peningkatan tiap tahun dan hal ini merupakan suatu pelanggaran atas peraturan perundang-undangan yang telah ditetapkan oleh pihak regulator. Berikut akan disajikan data dalam bentuk grafik mengenai fenomena keterlambatan pelaporan keuangan periode 2014-2018.

Berikut adalah data dalam kurun waktu 5 tahun terakahir pada tahun 2014 sampai 2018 surat yang dikeluarkan oleh Bursa Efek Indonesia dalam Audit Report Lag tahun buku yang berkahir di 31 Desember 2014 sampai 31 Desember 2018.

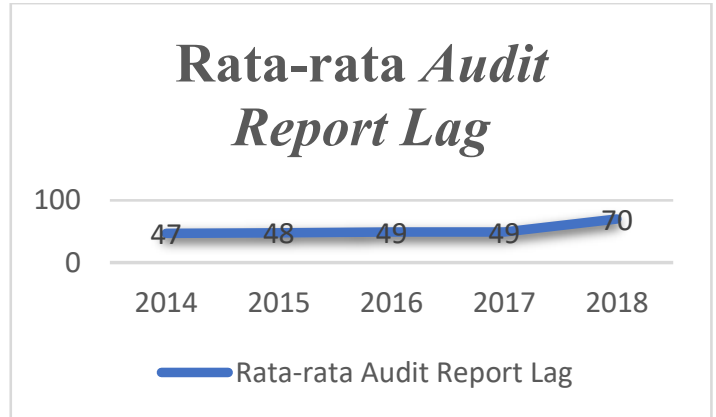

Sumber data di olah: $w w w . I d x . c o . i d$

Gambar 1.1

Grafik Fenomena Audit Report Lag

Berdasarkan grafik diatas menunjukan bahwa pada tahun 2014 dan 2015 menunjukan terdapat kenaikan sebesar 1\% , kemudian terdapat kenaikan kembali yaitu sebesar $1 \%$ dari tahun 2015 ke tahun 2016 kemudian mengalami peningkatan kembali yang cukup siginifikan di tahun tahun 2018 sebesar 21\%.
Fenomena ini sebaiknya dijadikan pembelajaran bagi setiap perusahaan agar menyampaikan laporan keuangannya sesuai batas waktu yang telah ditetapkan oleh OJK/Bapepam dan LK sehingga tidak menggangu dan memperlambat pekerjaan auditor indpenden dalam melakukan tugasnya untuk melaksanakan pemeriksaan dan pemberian opini /pendapat dari hasil pemeriksaan tersebut.

Salah satu bentuk profesionalitas auditor adalah ketepatan waktu penyampaian laporannya. Perbedaan waktu antara tanggal laporan keuangan dengan tanggal laporan auditor independen mengindikasi tentang lamanya waktu penyelesaian audit yang dilakukan oleh auditor. Perbedaan waktu ini sering disebut audit report lag. Menurut (Simanjorang, 2018)"Audit Report Lag adalah jumlah hari yang dibutuhkan oleh auditor untuk menyelesaikan proses audit yang dihitung dari tanggal berakhirnya tahun fiskal perusahaan sampai pada tanggal dimana proses audit itu selesai dikerjakan". Semakin lama audit report lag menunjukkan semakin lama auditor menyelesaikan pekerjaan audit, sehingga berdampak pada lamanya penerbitan laporan keuangan auditan ke OJK/BapepamLK.

Audit report lag merupakan periode antara akhir tahun fiskal perusahaan dengan tanggal dikeluarkannya opini pada laporan keuangan auditan, dan hal ini merupakan variabel output dari audit yang dapat di observasi oleh pihak eksternal yang memungkinkan pihak luar untuk mengukur efisiensi dari kegiatan audit (Habib \& Bhuiyan, 2011) Semakin panjang waktu audit report lag maka dapat mengakibatkan semakin berkurangnya relevansi informasi di dalam laporan keuangan. Hal ini dikarenakan salah satu hal yang dapat meningkatkan relevansi suatu laporan keuangan perusahaan adalah ketepatan waktu. Semakin lama suatu informasi maka semakin berkurang kegunaan dari informasi tersebut ( Ikatan Akuntan Indonesia, 2016). Oleh sebab itu, auditor memiliki tanggung jawab yang besar untuk menyelesaikan audit secara tepat waktu dan sesuai dengan regulasi-regulasi yang relevan.

Keterlambatan publikasi atas laporan keuangan perusahaan Go Public disebabkan karena laporan keuangan tersebut harus 
terlebih dahulu diaudit sebelum dipublikasi (Haryani \& Wiratmaja, 2014). Auditor independen dalam menyelesaikan pekerjaan audit membutuhkan sejumlah waktu tertentu untuk menyelesaikan pekerjaannya. Lamanya waktu penyelesaian audit yang diukur dari tanggal penutupan tahun buku atau akhir tahun fiskal hingga tanggal di terbitkannya laporan keuangan auditan disebut dengan audit report lag atau ARL (Pratiwi, 2009). Laporan keuangan memuat berbagai informasi penting, seperti laba, yang merupakan indikator kinerja perusahaan bagi investor dan digunakan sebagai dasar pertimbangan dalam pengambilan keputusan investasi sehingga audit report lag yang melewati batas waktu akan menimbulkan reaksi negatif dari perilaku pasar. (Arifa, 2013) menunjukkan bahwa pengumuman laba yang terlambat menyebabkan abnormal returns negatif sedangkan pengumuman laba yang lebih cepat menunjukkan hasil sebaliknya, karena investor pada umumnya menganggap keterlambatan pelaporan keuangan merupakan pertanda buruk bagi kondisi kesehatan perusahaan.

Auditor diwajibkan untuk melaksanakan proses audit sesuai dengan regulasi yang relevan dapat menghindarkan auditor dari sanksi-sanksi yang didapatkan apabila auditor melakukan pelanggaran. Hal ini sejalan dengan teori kepatuhan (compliance theory) yang dikemukan (Dewi, I. C., dan Hadiprajitno, 2017) yang menyebutkan bahwa organisasi dapat mematuhi peraturan dikarenakan organisasi menilai bahwa peraturan tersebut memiliki kewenangan untuk mengatur perilaku organisasi dalam hal ini yaitu perilaku auditor untuk mematuhi standar audit yang berlaku. Kepatuhan auditor terhadap standar audit yang berlaku dapat dijadikan salah satu cerminan dari profesionalitas yang dimiliki auditor. Apabila audit report lag semakin panjang menyebabkan adanya kemungkinan bahwa reputasi dari auditor bisa jatuh dikarenakan pemakai laporan keuangan ragu mengenai kualitas informasi yang dipublikasikan (Oktaviani, 2017).

Audit report lag dipengaruhi oleh berbagai faktor. (Pramaharjan \& Cahyonowati, 2015) menemukan bahwa Ukuran Kantor Akuntan Publik sebagai salah satu dari karakteristik tata kelola perusahaan (corporate governance) berpengaruh signifikan terhadap Perusahaan Manufaktur. Hasil penelitian ini sejalan dengan penelitian yang dilakukan oleh (Tiono, 2013) dan (Arifa, 2013)yang menyatakan bahwa Ukuran Kantor Akuntan Publik berpengaruh terhadap audit report lag. Dalam hal ini membuktikan bahwa KAP yang telah berlisensi sebagai the big Four memiliki sumber daya yang lebih besar, baik itu sebagai kompetensi, keahlian, dan kemampuan auditor serta fasilitas, sistem dan prosedur pengauditan yang lebih efektif dan efesien dalam melaksanakan pekerjaan audit. Namun, hasil ini tidak konsisten dengan hasil penelitian yang dilakukan (Michael \& Rohman, 2017) kemudian Shinta dan Abdul (2018) yang tidak menemukan hubungan signifikan antara Ukuan Kantor Akuntan Publik dengan audit report lag.

Berdasarkan uraian di atas, penelitian ini dilakukan atas dasar beberapa hal Pertama, dengan menyadari pentingnya perusahaan untuk menyampaikan laporan keuangan secara tepat waktu, maka auditor perlu mengetahui berbagai faktor yang mempengaruhi lamanya waktu yang dibutuhkan untuk menyelesaikan pekerjaan mereka dan mengendalikan faktor-faktor yang mempengaruhi audit report lag tersebut agar dapat ditekan seminimal mungkin. Kedua, berbagai penelitian sebelumnya mengenai Ukuran KAP dan profitabilitas perusahaan terhadap audit report lag masih menunjukkan hasil yang tidak konsisten. Ketiga, sampai dengan tahap penyelesaian penelitian ini, belum menemukan penelitian yang menguji apakah auditor spesialisasi industri memoderasi hubungan variabel independen Ukuran Kantor Akuntan Publik, profitabilitas perusahaan, ukuran perusahaan, audit tenure, dan investment opportunities set terhadap variabel dependen audit report lag secara positif atau negatif.

\section{Telaah Teori dan Pengembangan Hipotesis}

\subsection{Pengaruh antara ukuran kap dengan audit report lag}

Ketika manajemen perusahaan memilih KAP yang akan digunakan untuk audit laporan keuangannya, maka manajemen akan 
mempertimbangkan beberapa hal seperti reputasi KAP, kualitas auditor, serta keahlian auditor dalam industri khusus yang terkait dengan kegiatan industri perusahaan. Kantor Akuntan Publik yang bereputasi baik, diperkirakan dapat melakukan audit lebih cepat untuk menyelesaikan auditnya sesuai jadwal sehingga informasi yang didapatkan lebih cepatditerima pengguna laporan keuangan didalam pengambilan keputusan. Besarnya Kantor Akuntan Publik yang melaksanakan audit 61 laporan keuangan berdasarkan pada apakah Kantor Akuntan Publikvberafiliasi dengan The Big Four atau tidak. The Big Four akan cenderung lebih cepat dalam menyelesaikan audit dibandingkan dengan Non Big Four. Menurut hasil penelitian (Giyanto \& Rohman, 2019) dan (Herawaty \& Rusmawan, 2019) memberikan hasil bahwa tidak ada pengaruh yang signifikan antara Ukuran KAP dengan audit report lag, namun berbeda dengan hasil penelitian yang dilakukan (Pramaharjan \& Cahyonowati, 2015) serta (Arifa, 2013) yang menemukan ada pengaruh dari ukuran KAP terhadap audit report lag.

Ketika manajemen perusahaan memilih KAP yang akan digunakan untuk audit laporan keuangannya, maka manajemen akan mempertimbangkan beberapa hal seperti reputasi KAP, kualitas auditor, serta keahlian auditor dalam industri khusus yang terkait dengan kegiatan industri perusahaan. Kantor Akuntan Publik yang bereputasi baik, diperkirakan dapat melakukan audit lebih cepat untuk menyelesaikan auditnya sesuai jadwal sehingga informasi yang didapatkan lebih cepatditerima pengguna laporan keuangan didalam pengambilan keputusan

Menurut hasil penelitian Sinta dan Abdul (2017) memberikan hasil bahwa tidak ada pengaruh yang signifikan antara Ukuran KAP dengan audit report lag, namun berbeda dengan hasil penelitian yang dilakukan (Pramaharjan \& Cahyonowati, 2015)dan (Arifa, 2013)) serta (Herawaty \& Rusmawan, 2019)) yang menemukan auditor spesialisasi industri memoderasi pengaruh dari ukuran KAP terhadap audit report lag.Dari uraian hasil penelitian sebelumnya, maka diduga bahwa auditor spesialisasi industri merupakan variabel moderating antara Ukuran KAP dan audit report lag.
$\mathrm{H}_{\mathrm{a}}$ : Ukuran KAP berpengaruh secara signifikan terhadap audit report lag.

$\mathrm{H} 1_{\mathrm{b}}$ : Interaksi antara ukuran KAP dengan auditor spesialisasi industri berpengaruh secara signifikan terhadap audit report lag.

\subsection{Pengaruh antara profitabilitas perusahaan dengan audit report lag}

Rasio profitabilitas merupakan keberhasilan perusahaan di dalam menghasilkan keuntungan. Profitabilitas suatu perusahaan mencerminkan tingkat efektifitas yang dicapai oleh suatu operasional perusahaan. Dasar pemikiran bahwa tingkat keuntungan dipakai sebagai salah satu cara untuk menilai keberhasilan efektifitas perusahaan, tentu saja berkaitan dengan hasil akhir dari berbagai kebijakan dan keputusan perusahaan yang telah dilaksanakan oleh perusahaan dalam periode berjalan. Indikator rasio profitabilitas yang digunakan dalam penelitian ini adalah ROI (Return On Invesment). Menurut hasil penelitian yang dilakukan dilakukan (Pramaharjan \& Cahyonowati, 2015) serta (Nelson \& Shukeri, 2011)yang memberikan hasil penelitianya bahwa terdapar pengaruh antara profitabilitas dengan audit report lag namun berbeda dengan penelitian yang dilakukan (Tiono, 2013) serta (Herawaty \& Rusmawan, 2019)yang tidak menemukan adanya pengaruh antara profitabilitas dengan audit report lag.

Profitabilitas adalah kemampuan perusahaan memperoleh laba dalam hubungan dengan penjualan total aktiva maupun modal sendiri (Sugiyarso, G., Winarni, 2005). Profitabilitas menunjukkan keberhasilan perusahaan dalam menghasilkan keuntungan (Lianto, N, 2010). Investor melihat profitabilitas sebagai informasi yang penting dalam mempertimbangkan keputusan investasi karena semakin besar laba yang dihasilkan di masa mendatang pada akhirnya akan meningkatkan tingkat pengembalian modal dari investor.

Penelitian yang dilakukan oleh (Pratiwi, 2009) mengenai faktor-faktor yang mempengaruhi audit report lag dengan sampel 62 perusahaan manufaktur dan finansial yang terdaftar dalam Bursa Efek Indonesia (BEI) tahun 2006-2008 menunjukkan bahwa jenis 
industri, profitabilitas dan ukuran KAP yang berpengaruh terhadap audit report lag. Hasil penelitian ini mendukung hasil penelitian yang dilakukan oleh (Nelson \& Shukeri, 2011), Pramaharjan dan Cahyonowati (2015) yang menemukan bahwa profitabilitas mempengaruhi audit report lag. Namun, hasil penelitian ini bertolak belakang dengan hasil penelitian (Tiono, 2013) dan (Fadoli, 2015)yang tidak menemukan pengaruh signifikan antara profitabilitas dengan audit report lag.

Penelitian yang dilakukan oleh (Habib \& Bhuiyan, 2011) mengenai pengaruh spesialisasi auditor terhadap audit report lag (ARL) pada perusahaan - perusahaan yang listing di New Zealand Stock Exchange (ZX) tahun 2004-2005 menunjukan hasil bahwa perusahaan - perusahaan yang diaudit oleh auditor spesialis industri menghasilkan audit report lag (ARL) lima hari lebih cepat dibandingkan perusahaan yang diaudit oleh audit yang bukan merupakan spesialis industri.

Dari uraian hasil penelitian sebelumnya, maka diduga bahwa auditor spesialisasi industri merupakan variabel moderating antara profitabilitas dan audit report lag.

$\mathrm{H} 2_{\mathrm{a}}$ : Profitabilitas berpengaruh secara signifikan terhadap audit report lag.

$\mathrm{H} 2 \mathrm{~b}$ : Interaksi antara profitabilitas dengan auditor spesialisasi industri berpengaruh secara signifikan terhadap audit report lag.

\subsection{Pengaruh antara ukuran perusahaan dengan audit report lag}

Ukuran Perusahaan adalah suatu skala dimana dapat diklasifikasikan besar kecilnya perusahaan menurut berbagai cara antara lain dengan total aset. Besar kecilnya perusahaan akan mempengaruhi kemampuan dalam menanggung risiko yang mungkin timbul dari berbagai situasi yang dihadapi perusahaan. Perusahaan besar memiliki resiko yang lebih rendah dibandingkan dengan perusahaan kecil. Hal ini dikarenakan perusahaan besar memiliki kontrol yang lebih baik terhadap kondisi pasar sehingga mereka mampu mengahadapi persaingan ekonomi. Menurut penelitian yang dilakukan oleh (Pramaharjan \& Cahyonowati, 2015), Reinzky dan Majidah
(2016) menemukan bahwa ukuran perusahaan berpengaruh terhadap audit report lag, namun berbebda dengan penelitian yang dilakukan Putu dan Yeni (2016) dan Yogi, Pupung dan Maemunah (2016) yang tidak menemukan adanya pengaruh antara ukuran perusahaan terhadap audit report lag.

Dalam mengukur suatu perusahaan dapat didasarkan pada nilai buku aset yang dimiliki perusahaan. Semakin besar ukuran suatu perusahaan maka semakin rumit pula proses dalam melakukan auditnya. Terkait komponen dalam audit report lag, ukuran perusahaan mempengaruhi seluruh komponen baik scheduling, fieldwork, dan reporting lag. Hasil penelitian yang mengungkapkan bahwa ukuran perusahaan berpengaruh terhadap audit report lag hal ini sejalan dengan penelitian yang dilakukan oleh Brian dan Cahyonowati (2015), serta Ivena dan Yulius (2014). Namun, berbeda penelitian Muhammad Yogi, Pupung dan Maemunah (2016) dan Fadoli (2015) yang tidak menemukan auditor spesialisasi industry memoderasi pengaruh signifikan antara ukuran perusahaan dengan audit report lag oleh karena itu rumusan untuk hipotesis ini adalah sebagai berikut :

$\mathrm{H} 3_{\mathrm{a}}$ : Ukuran Perusahaan berpengaruh secara signifikan terhadap audit report lag.

$\mathrm{H} 3_{\mathrm{b}}$ : Interaksi antara Ukuran Perusahaan dengan auditor spesialisasi industri berpengaruh secara signifikan terhadap audit report lag.

\subsection{Pengaruh antara audit tenur dengan audit report lag}

Dalam proses audit dibutuhkan hubungan kerja yang erat dengan manajemen perusahaan sebagai pihak klien. Hubungan perikatan audit dengan manajemen perusahaan (klien) disebut dengan tenure audit. Jika jangka waktu perikatan audit semakin panjang maka menimbulkan ketergantungan yang menyebabkan auditor mulai kehilangan independensinya. Oleh karena itu auditor harus menyadari bahwa ancaman terhadap independensi dan objektivitas membutuhkan pengamanan yang sesuai, Dewi (2014). Menurut penelitian Yogi, Pupung dan Maemunah (2016) tidak 
ada pengaruh yang siginifkan antara audit tenur dan audit report lag berbeda denga hasil penelitian yang dilakukan oleh Michael (2017) dan (Riensky Dewangga Putra, Dr. Majidah, S.E., 2016) yang menemukan adanya pengaruh yang siginifikan antara audit tenur dengan audit report lag.

Audit tenure merupakan jangka waktu masa perikatan kerja antara auditor dengan kliennya dalam pemeriksaan laporan. Tenure yang panjang dari suatu KAP dapat meningkatkan pemahaman bagi auditor tentang bisnis kliennya (Ferdinan Giri, 2012). Ada berbagai diskusi tentang persoalan kewajiban rotasi perusahaan audit. Rotasi perusahaan audit biasanya memberi perhatian lebih tentang biaya perubahan auditor. (Ross, A. S., Westerfield, R. W., Jordan, B. D., Lim, J., \& Tan, 2012)) menyatakan pendapat bilamana mengganti auditor bisa mempengaruhi kualitas audit. Hal tersebut terjadi karena auditor mempunyai pemahaman yang kurang memadai tentang kliennya dan industri selama tahun-tahun awal perikatan audit. Sementara itu, beberapa peneliti menyatakan bahwa auditor yang memiliki tenure panjang bisa memiliki sifat yang kurang objektif dan skeptis, sehingga bisa memberikan pengaruh terhadap kualitas audit. Seperti yang sudah dijelaskan sebelumnya, selain biaya potensial dan kemungkinan penurunan kualitas audit terkait untuk rotasi perusahaan audit, audit report lag akan panjang pada beberapa tahun awal hubungan audit antara auditor dengan klien. Hal ini dikarenakan dibutuhkan waktu untuk memahami operasi dan industri klien. Dengan kata lain, audit report lag diharapkan panjang ketika audit tenure pendek. Masa audit yang singkat dapat membuat keterlambatan dalam informasi yang diberikan auditor kepada pasar yang tidak familiar dengan operasi perusahaan (Habib \& Bhuiyan, 2011). Dengan demikian, dapat dinyatakan bahwa masa audit yang singkat dapat menyebabkan kenaikan biaya dan informasi yang tidak efisien.

Penelitian yang dilakukan oleh (Habib \& Bhuiyan, 2011) meneliti efek spesialisasi industri auditor pada hubungan audit tenure terhadap audit report lag. Penelitian tersebut menunjukkan bahwa audit tenure berpengaruh secara negatif terhadap audit report lag, namun hal tersebut dapat dikurangi jika laporan keuangan diaudit oleh auditor spesialis industri. Hal tersebut terjadi karena auditor spesialis memiliki pengetahuan yang spesifik atas suatu industri yang berperan sangat penting dalam penanganan audit. Dengan demikian, spesialisasi industri auditor diharapkan dapat meperlemah hubungan positif antara audit tenure yang pendek terhadap audit report lag, serta memperkuat hubungan negatif audit tenure yang panjang.

Beberapa penelitian pernah dilakukan untuk menguji pengaruh dari audit tenure terhadap audit report lag. Hasil penelitian yang dilakukan oleh (Pham et al., 2014) menunjukkan bahwa audit tenure pendek (perikatan auditor-klien selama 3 tahun).

Dari uraian hasil penelitian sebelumnya, maka diduga bahwa auditor spesialisasi industri merupakan variabel moderating antara fungsi internal audit dan audit report lag. Menurut penelitian (Yogi et al., 2017) tidak ada pengaruh yang siginifkan antara audit tenur dan audit report lag berbeda denga hasil penelitian yang dilakukan oleh (Michael \& Rohman, 2017) dan (Riensky Dewangga Putra, Dr. Majidah, S.E., 2016)yang menemukan adanya pengaruh yang siginifikan antara audit tenur dengan audit report lag. Serta penelitian yag dilakuka (Anggreni \& Latrini, 2016), (Putu dan Gede, 2017) yang menemukan bahwa auditor spesiaisasi industri memoderasi audit tenur terhadap audit report la. Oleh karena itu rumusan untuk hipotesis ini adalah sebagai berikut:

$\mathrm{H}_{4}$ : Audit Tenure berpengaruh secara signifikan terhadap audit report lag.

$\mathrm{H} 4_{\mathrm{b}}$ : Interaksi antara Audit Tenur dengan auditor spesialisasi industri berpengaruh secara signifikan terhadap audit report lag.

\subsection{Pengaruh antara invesment opportunity Set terhadap audit report lag}

Perusahaan adalah kombinasi antara nilai asset in place dengan pilihan investasi di masa yang akan datang. Pilihan investasi merupakan suatu kesempatan untuk berkembang, namun seringkali perusahaan tidak selalu dapat melaksanakan semua kesempatan investasi di masa mendatang. 
Bagi perusahaan yang tidak dapat menggunakan kesempatan investasi tersebut akan mengalami suatu pengeluaran yang lebih tinggi dibandingkan dengan nilai kesempatan yang hilang. Nilai kesempatan investasi merupakan nilai sekarang dari pilihan-pilihan perusahaan untuk membuat investasi di masa mendatang. Menurut penelitian yang dilakukan oleh (Cakra, 2017) dan (Pham et al., 2014) memberikan hasil bahwa da pengaruh antara Invesment Opportunity Set terhadap audit report lag namun berbeda dengan penelitian yang dilakukan oleh Brian dan Cahyonowati (2015) yang tidak menemukan adanya pengaruh Invesment Opportunity Set terhadap audit report lag.

Investment Opportunity Set adalah tersedianya alternative untuk investasi di masa datang bagi perusahaan. IOS merupakan suatu keputusan investasi yang merupakan bentuk kombinasi antara aktiva yang dimiliki (assets in place) dan pilihan investasi dimasa yang akan datang. Menurut (Gaver, Jeniffer J., 1993), IOS merupakan nilai perusahaan yang besarnya tergantung pada pengeluaranpengeluaran yang ditetapkan manajemen di masa yang akan datang, yang pada saat ini merupakan pilihan-pilihan investasi yang diharapkan akan menghasilkan return yang lebih besar. Maka dari itu, perusahaan harus melakukan perencanaan yang matang dalam mengalokasikan dana terkait keputusan investasi di masa depan karena akan menentukan keuntungan yang diperoleh terkait kegiatan investasi tersebut.

Penelitian yang dilakukan oleh (Pham et al., 2014)mengenai pengaruh kesempatan investasi dan audit report lag pada 8520 perusahaan di Amerika Serikat periode 20102012 menunjukkan hasil bahwa perusahaan yang memiliki kesempatan investasi yang tinggi akan cenderung lebih lama dalam menyampaikan laporan keuangannya, maka investment opportunities set berpengaruh secara signifikan terhadap audit report lag.

Set kesempatan investasi yang tinggi pada perusahaan akan meningkatkan risiko audit sehingga auditor independen harus memperluas ruang lingkup kerja audit agar dapat memetakan risiko audit dengan matang dalam rangka menentukan rencana kerja audit yang tepat. Auditor spesialisasi mempunyai pemahaman yang superior atas suatu industri sehingga dapat dengan mudah memetakan risiko audit dengan efisien, sehingga mempersingkat proses audit yang dilakukan dan akan mengurangi penundaan penyampaian laporan keuangan

Dari uraian hasil penelitian sebelumnya, maka diduga bahwa auditor spesialisasi industri merupakan variabel moderating antara investment opportunities set dan audit report lag. Menurut penelitian yang dilakukan oleh (Cakra, 2017) dan (Pham et al., 2014) memberikan hasil bahwa da pengaruh antara Invesment Opportunity Set terhadap audit report lag namun berbeda dengan penelitian yang dilakukan oleh (Pramaharjan \& Cahyonowati, 2015) yang tidak menemukan adanya pengaruh Invesment Opportunity Set terhadap audit report lagoleh karena itu rumusan untuk hipotesis ini adalah sebagai berikut :

$\mathrm{H} 5 \mathrm{a}$ : Invesment Opportunity Set tidak berpengaruh secara signifikan terhadap audit report lag.
$\mathrm{H} 5_{\mathrm{b}}$ : Interaksi antara investment opportunities set dengan auditor spesialisasi industri berpengaruh secara signifikan terhadap audit report lag.

\section{Metode Penelitian}

Penelitian ini bertujuan untuk menganalisa hubungan kausalitas yang digunakan untuk menjelaskan pengaruh variabel independen, yaitu opini audit, profitabilitas, ukuran perusahaan, audit tenur, dan investment opportunities set terhadap variabel dependen, yaitu audit report lag dengan auditor spesialisasi industri sebagai variabel moderating. Populasi penelitian ini adalah seluruh perusahaan BUMN yang terdaftar di Bursa Efek Indonesia (BEI) periode waktu 2014, 2015, 2016, 2017, dan 2018.

Metode yang digunakan peneliti dalam pemilihan sample penelitian adalah pemilihan sampel bertujuan (purposive sampling) dengan kriteria sebagai berikut: 
Tabel 3.1

Proses Seleksi Sampel Berdasarkan Kriteria

\begin{tabular}{|c|c|c|}
\hline NO & KRITERIA & JUMLAH \\
\hline 1 & $\begin{array}{l}\text { Perusahaan BUMN Go } \\
\text { Public yang terdaftar } \\
\text { Bursa Efek Indonesia }\end{array}$ & 20 \\
\hline 2 & $\begin{array}{l}\text { Perusahaan BUMN Go } \\
\text { Public yang tidak konsisten } \\
\text { terdaftar di BEI secara } \\
\text { berturut-turut pada periode } \\
2014 \text { sampai dengan } 2018\end{array}$ & (0) \\
\hline 3 & $\begin{array}{l}\text { Perusahaan yang tidak } \\
\text { menerbitkan laporan } \\
\text { keuangan auditan dan } \\
\text { dipublikasikan pada periode } \\
2014 \text { sampai dengan } 2018\end{array}$ & $(0)$ \\
\hline 4 & $\begin{array}{l}\text { Data dan informasi tidak } \\
\text { lengkap }\end{array}$ & (0) \\
\hline & SAMPEL & 20 \\
\hline
\end{tabular}

Penelitian ini menggunakan data sekunder dalam bentuk laporan keuangan auditan dan laporan audit. Jangka waktu laporan auditan dan laporan audit adalah 2014-2018 yang diperoleh dari situs resmi Bursa Efek Indonesia. www.idx.co.id dan Sahamok.com. Data dikumpulkan dengan metode dokumentasi tentang hal-hal dan dokumen yang berkaitan dengan variabel penelitian. Data yang diperlukan antara lain informasi tentang Pengungkapan Audit Report Lag, Auditor Spesialisasi Industri, Ukuran KAP, Profitabilitas, Ukuran Perusahaan, Audit Tenur, dan Invesment Oportunity Set yang dimana semuanya tertuang dalam Laporan Keuangan dan Laporan Tahunan Perusahaan.

Tabel 3.2

Operasionalisasi Variabel

\begin{tabular}{|c|c|c|c|c|}
\hline No & Variabel & Indikator & Skala & Referensi \\
\hline 1 & $\begin{array}{c}\text { Audit Report } \\
\text { Lag }\end{array}$ & $\begin{array}{l}\text { Variabel atudir report lag diukur } \\
\text { dari periode berakhir per } 31 \\
\text { Desember sampai tanggal yang } \\
\text { tertera pada laporan ketuangan } \\
\text { audited }\end{array}$ & $\begin{array}{c}\text { Skala } \\
\text { Interval }\end{array}$ & $\begin{array}{l}\text { Soetedjo } \\
(2006)\end{array}$ \\
\hline 2. & $\begin{array}{l}\text { Auditor } \\
\text { Spesialisasi } \\
\text { Industri }\end{array}$ & 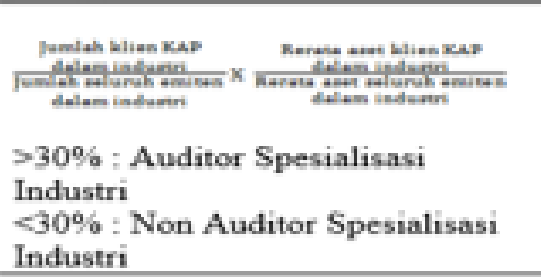 & $\begin{array}{l}\text { Skala } \\
\text { Rasio }\end{array}$ & $\begin{array}{l}\text { Setiawan } \\
\text { dan } \\
\text { Fitriyani } \\
\text { (2011) }\end{array}$ \\
\hline 3. & Ukuran KAP & $\begin{array}{l}\text { Menggunakan Variabel Dummy } \\
\text { apabila di audit oleh KAP the big } \\
\text { foter maka di beri poin } 1 \text { apabila } \\
\text { tidak di audit oleh KAP non the big } \\
\text { fotur di beri angka } 0\end{array}$ & $\begin{array}{c}\text { Skala } \\
\text { Interval }\end{array}$ & $\begin{array}{l}\text { Putu dan } \\
\text { Gede } \\
(2017)\end{array}$ \\
\hline 4 & $\begin{array}{c}\text { Profitablitas/ } \\
\text { ROI }\end{array}$ & $R O I=\frac{E A T}{\text { Total Assets }} \times 100 \%$ & $\begin{array}{l}\text { Skala } \\
\text { Rasio }\end{array}$ & $\begin{array}{l}\text { Cakra } \\
(2017)\end{array}$ \\
\hline 5 & $\begin{array}{c}\text { Ukuran } \\
\text { Perusahaan }\end{array}$ & $\begin{array}{l}\text { Variabel ukuran perusahaan } \\
\text { menggunakan logaritma natural } \\
\text { total aset (LnTA) }\end{array}$ & $\begin{array}{c}\text { Skala } \\
\text { Interval }\end{array}$ & $\begin{array}{c}\text { Yogi } \\
(2016)\end{array}$ \\
\hline 6 & Audit Tenur & $\begin{array}{l}\text { Tahun pertama perikatan dimulai } \\
\text { dengan angka } 1 \text { dan ditambah } \\
\text { dengan satu untuk tahun-tahun } \\
\text { selanjutnya. Selama periode } \\
\text { penelitian 2014-2018 }\end{array}$ & $\begin{array}{c}\text { Skala } \\
\text { Nominal }\end{array}$ & $\begin{array}{l}\text { Putu dan } \\
\text { Gede } \\
(2017)\end{array}$ \\
\hline 7 & $\begin{array}{l}\text { Invesment } \\
\text { Oportunity } \\
\text { Set }\end{array}$ & $\begin{array}{l}\text { MVE/BVE : } \frac{\text { LSB X HPS }}{\text { Total Ekuitas }} \\
\text { Keterangan: } \\
\text { LSB : Jumlah Lembar Saham } \\
\text { Beredar } \\
\text { HPS : Harga Penutupan Saham }\end{array}$ & $\begin{array}{l}\text { Skala } \\
\text { Rasio }\end{array}$ & $\begin{array}{l}\text { Fitrijanti } \\
\text { dan } \\
\text { Hartono } \\
(2012)\end{array}$ \\
\hline
\end{tabular}


Metode analisis data adalah suatu metode yang digunakan untuk mengolah hasil penelitian guna memperoleh suatu kesimpulan. Dengan melihat kerangka pemikiran teoritis, maka teknik analisis data yang digunakan dalam penelitian ini adalah analisis kuantitatif. Dalam penelitian ini analisis yang digunakan untuk mengetahui pengaruh ukuran kap, profitabilitas, ukuran perusahaan, audit tenur dan investment opportunity set terhadap audit report lag, menggunakan analisis regresi linier berganda. Kemudian dalam penelitian ini terdapat variabel moderasi yang untuk mengetahui apakah variabel auditor spesialisasi industri dapat memoderasi atau tidak dari variabel faktor-faktor yang mempengaruhi audit report lag seperti ukuran kap, profitabilitas, ukuran perusahaan, audit tenur dan investment opportunity set, dengan menggunakan analisis regresi moderate. Persamaan regresi adalah sebagai berikut.

$$
\begin{aligned}
A R L= & \alpha+\beta 1 \mathrm{UKAP}+\beta 2 \mathrm{ROI}+\beta 3 \mathrm{UP}+\beta 4 \mathrm{AT}+ \\
& \beta 5 \mathrm{IOS}+\beta \mathrm{MASI} \beta 6(\mathrm{UKAP} * \mathrm{ASI})+ \\
& \beta 7\left(\mathrm{ROI}^{*} \mathrm{ASI}\right)+\beta 8\left(\mathrm{UP}^{*} \mathrm{ASI}\right)+ \\
& \beta 9\left(\mathrm{AT}^{*} \mathrm{ASI}\right)+\beta 10\left(\mathrm{IOS}^{*} \mathrm{ASI}\right)
\end{aligned}
$$

Keterangan:

ARL $=$ Audit Report Lag

$\alpha=$ Konstanta

$\beta=$ Koefisien Regresi

UKAP $=$ Ukuran KAP

ROI $=$ Profitabilitas

$\mathrm{UP}=$ Ukuran Perusahaan

$\mathrm{AT}=$ Audit Tenure

$\mathrm{IOS}=$ Investment Opportunities Set

ASI $=$ Auditor Spesialisasi Industri

Pengambilan keputusan didasarkan pada pengaruh hubungan antara variabel independen dengan variabel dependen dapat dilihat dari taraf signifikansinya yaitu 5\% atau 0.05 (Ghozali, 2018). Apabila hasil perhitungan signifikansi yang diperoleh lebih dari 5\% atau 0.05 maka Ho diterima dan $\mathrm{Ha}$ ditolak, apabila tingkat signifikansinya sama dengan atau kurang dari 5\% atau 0.05 maka Ho ditolakdan Ha diterima.

Variabel moderasi dapat diklasifikasikan menjadi 4 jenis yaitu pure moderasi (moderasi murni), quasi moderasi (moderasi semu), homologiser moderasi (moderasi potensial) dan Predictor moderasi (moderasi sebagai predictor).
Masing-masing klasifikasi moderasi dapat diidentifikasi sebagaimana table berikut :

Tabel 3.3

Klasifikasi Variabel Moderasi

\begin{tabular}{|c|l|l|}
\hline No. & \multicolumn{1}{|c|}{ Tipe Moderasi } & \multicolumn{1}{|c|}{ Koefisien } \\
\hline 1. & Pure Moderasi & $\begin{array}{l}\text { bM non significant } \\
\text { bX significant }\end{array}$ \\
\hline 2. & Quasi Moderasi & $\begin{array}{l}\text { bM significant } \\
\text { bX significant }\end{array}$ \\
\hline 3. & $\begin{array}{l}\text { Homologiser } \\
\text { Moderasi }\end{array}$ & $\begin{array}{l}\text { bM nonsignificant } \\
\text { bX nonsignificant }\end{array}$ \\
\hline 4. & $\begin{array}{l}\text { Predictor } \\
\text { Moderasi }\end{array}$ & $\begin{array}{l}\text { bM significant } \\
\text { bX nonsignificant }\end{array}$ \\
\hline
\end{tabular}

\begin{tabular}{|c|c|c|c|c|c|c|}
\hline \multirow[b]{2}{*}{ Mode } & & \multicolumn{2}{|c|}{$\begin{array}{c}\text { Unstandardized Coeffi- } \\
\text { cients }\end{array}$} & \multirow{2}{*}{\begin{tabular}{|c|}
$\begin{array}{c}\text { Standardized } \\
\text { Coefficients }\end{array}$ \\
Beta \\
\end{tabular}} & \multirow[b]{2}{*}{$t$} & \multirow[b]{2}{*}{ Sig. } \\
\hline & & B & Std. Error & & & \\
\hline \multirow[t]{12}{*}{$l_{1}$} & (Constant) & 232.919 & 40.974 & & 5.684 & .000 \\
\hline & UKAP & -2.783 & 8.097 & -.055 & -.344 & .732 \\
\hline & ROI & -2.313 & 1.053 & -.436 & -2.196 & .031 \\
\hline & UP & -27.266 & 5.652 & -.968 & -4.824 & .000 \\
\hline & AT & 15.226 & 3.918 & .711 & 3.886 & .000 \\
\hline & IOS & -.045 & .503 & -.015 & -.090 & .929 \\
\hline & ASI & -139.568 & 61.000 & -2.291 & -2.288 & .025 \\
\hline & UKAP_ASI & 19.007 & 13.969 & .338 & 1.361 & .177 \\
\hline & ROI_ASI & 3.874 & 1.465 & .695 & 2.645 & .010 \\
\hline & UP_ASI & 17.961 & 8.521 & 2.169 & 2.108 & .038 \\
\hline & AT_ASI & -11.917 & 5.885 & -.500 & -2.025 & .046 \\
\hline & IOS ASI & -.142 & .703 & -.036 & -.203 & .840 \\
\hline
\end{tabular}

\section{Hasil Penelitian dan Pembahasan}

Tabel 4.1

Hasil Uji Moderated Regression Analysis (MRA)

Dari tabel tersebut dapat diketahui bahwa variabel ukuran kantor akuntan publik dan investment opportunity set tidak memiliki pengaruh terhadap audit report lag. Sedangkan untuk variabel profitabilitas, ukuran perusahaan dan audit tenure memiliki pengaruh signifikan terhadap audit report lag. Kemudian interaksi antara ukuran kantor akuntan publik, investment opportunity set dengan auditor spesialisasi industri memperlemah terhadap audit report lag dan membentuk hubungan moderasi homologesier, namun interkasi profitabilitas, ukuran perusahaan dan audit tenure dengan auditor spesialisasi industri memperkuat hubungan dengan audit report lag dan membentuk hubungan moderasi semu.

\subsection{Pengaruh Ukuran KAP terhadap Audit Report Lag dan Peran Audit Spesialisasi Industri}

Hasil uji hipotesis pertama dapat dilihat pada tabel 4.8, variabel ukuran KAP mempunyai tingkat signifikansi sebesar 0.732 (p-value $>0.05$ ) dan 
koefiesien regresi dengan arah negatif sebesar 0.055 .

Hal ini dapat dikatakan bahwa hipotesis pertama ditolak sehingga dapat dikatakan bahwa ukuran KAP tidak berpengaruh secara signifikan terhadap audit report lag karena tingkat siginifikansi yang dimiliki variabel ukuran KAP lebih besar dari 0.05 yaitu 0.732 sehingga kesimpulan untuk hipotesis pertama H1 ditolak dan $\mathrm{H} 0$ diterima.

Bedasarkan hasil diatas temuan ini mendukung dan sejalan dengan hasil penelitian yang dilakukan Menurut hasil penelitian (Giyanto \& Rohman, 2019) serta (Herawaty \& Rusmawan, 2019)yang memberikan hasil bahwa tidak ada pengaruh yang signifikan antara Ukuran KAP dengan audit report lag, artinya bahwa besar atau kecilnya kantor akuntan publik atau KAP tersebut berafiliasi dengan KAP the big four tidak akan memberikan pengaruh untuk mempercepat pemeriksaan yang dilakukan dan tidak memberikan pengaruh kepada manajemen atau perusahaan memberikan keyakinan bahwa jika diaudit oleh KAP the big four penyampaian laporan keuangan yang telah diaudit oleh auditor independen dapat disampaikan tepat waktu. namun penelitian ini tidak sejalan penelitian yang dilakukan (Pramaharjan \& Cahyonowati, 2015) serta (Arifa, 2013) yang menemukan ada pengaruh dari ukuran KAP terhadap audit report lag. secara teori yang mengatakan apabila diaudit oleh KAP the big four akan semakin rendah waktu yang di butuhkan auditor untuk mengerjakan penyelesaian tugas audit nya karena memberikan profesionalitas dan kinerja yang dilakukan oleh SDM yang mengaudit lebih kompeten dan efektif serta efisien secara prosedur dan pekerjaan yang dilakukan karena memiliki kapabilitas yang memadai.

\subsection{Pengaruh Profitabilitas Perusahaan (ROI) terhadap Audit Report Lag dan Peran Audit Spesialisasi Industri}

Hasil uji hipotesis kedua dapat dilihat pada tabel 4.8, variabel profitabilitas perusahaan mempunyai tingkat signifikansi sebesar 0.031 (pvalue $<0.05$ ) dan koefiesien regresi dengan arah negatif sebesar -0.436 .

Hal ini dapat dikatakan bahwa hipotesis kedua diterima sehingga dapat dikatakan bahwa profitabilitas perusahaan yang di proksikan dengan ROI berpengaruh secara signifikan terhadap audit report lag karena tingkat siginifikansi yang dimiliki variabel profitabilitas perusahaan (ROI) lebih kecil dari 0.05 yaitu sebesar 0.031 sehingga kesimpulan untuk hipotesis kedua $\mathrm{H} 2$ diterima dan H0 ditolak.

Bedasarkan hasil diatas temuan ini tidak mendukung dan sejalan dengan penelitian yang dilakukan (Tiono, 2013), (Michael \& Rohman, 2017) dan (Yuliesti Rosalia, Kurnia, 2019) yang tidak menemukan adanya pengaruh antara profitabilitas dengan audit report lag. artinya adanya atau tidak tingkat efektifitas operasional perusahaan tidak akan memberikan pengaruh terhadap penyampaian laporan keuangan yang telah diaudit oleh auditor independen, namun berbeda dengan menurut hasil penelitian yang dilakukan dilakukan (Pramaharjan \& Cahyonowati, 2015) serta (Nelson \& Shukeri, 2011) yang memberikan hasil penelitianya bahwa terdapat pengaruh antara profitabilitas dengan audit report lag yang secara teoritis memberikan penjelasan bahwa berhasil operasional dan produktivitas perusahaan yang efektif dan efisien akan memberikan jaminan bahwa kinerja keuangan yang dilakukan selama satu periode berjalan dapat dikatakan baik, sehingga dalam hal menuangkan informasi dalam laporan keuangan yang mana sebagai produk akhir dan akan di periksa oleh auditor independen kemudian di pertanggung jawabkan oleh para pengguna informasi akan dilakukan secara tepat waktu dan menghasilkan timbal balik yang baik bagi manajemen dan perusahaan. Karena dengan profittabilitas yang tinggi memberikan sinyal bahwa audit report lag akan semakin rendah sehingga pekerjaan dan tugas auditor independen dalam melakukan pemeriksaan akan semakin singkat, karena didukung dengan pihak manajemen yang taat dan patuh terhadap peraturan yang berlaku dalam melakukan mekanisme bisnis yang baik dan sehat.

\subsection{Pengaruh Ukuran Perusahaan terhadap Audit Report Lag dan Peran Audit Spesialisasi Industri}

Hasil uji hipotesis kedua dapat dilihat pada tabel 4.8, variabel ukuran Perusahaan mempunyai tingkat signifikansi sebesar 0.000 ( $p$-value $<0.05$ ) dan koefiesien regresi dengan arah negatif sebesar -0.968 .

Hal ini dapat dikatakan bahwa hipotesis ketiga diterima sehingga dapat dikatakan bahwa ukuran perusahaan berpengaruh secara signifikan terhadap audit report lag karena tingkat siginifikansi yang dimiliki variabel profitabilitas perusahaan lebih kecil dari 0.05 yaitu sebesar 0.000 sehingga 
kesimpulan untuk hipotesis kedua $\mathrm{H} 3$ diterima dan $\mathrm{H} 0$ ditolak.

Bedasarkan hasil diatas temuan ini mendukung dan sejalan dengan penelitian yang dilakukan oleh (Pramaharjan \& Cahyonowati, 2015), (Riensky Dewangga Putra, Dr. Majidah, S.E., 2016)menemukan bahwa ukuran perusahaan berpengaruh terhadap audit report lag, yang memberikan arti bahwa Perusahaan besar memiliki resiko yang lebih rendah dibandingkan dengan perusahaan kecil. Hal ini dikarenakan perusahaan besar memiliki kontrol yang lebih baik terhadap kondisi pasar sehingga mereka mampu mengahadapi persaingan ekonomi sehingga dengan kontrol yang baik pun seluruh komponen serta peraturan yang dibuat oleh para pihak regulasi dapat dipatuhi dan dipenuhi dengan mudah dan baik. dengan hal tersebut memberikan efek kepada terjadinya audit report lag akan semakin rendah. Namun berbebda dengan penelitian yang dilakukan (Sastrawan \& Latrini, 2016) dan (Yogi et al., 2017) yang tidak menemukan adanya pengaruh antara ukuran perusahaan terhadap audit report lag yang secara teori bahwa banyaknya asset yang dimiliki suatu perusahaan tidak berpengaruh terhadap lama atau singkatnya audit report lag.

\subsection{Pengaruh Audit Tenur terhadap Audit Report Lag dan Peran Audit Spesialisasi Industri}

Hasil uji hipotesis kedua dapat dilihat pada tabel 4.8, variabel audit tenur mempunyai tingkat signifikansi sebesar 0.000 (p-value $<0.05$ ) dan koefiesien regresi dengan arah positif sebesar 0.711 .

Hal ini dapat dikatakan bahwa hipotesis keempat diterima sehingga dapat dikatakan bahwa audit tenure berpengaruh secara signifikan terhadap audit report lag karena tingkat siginifikansi yang dimiliki variabel audit tenur lebih kecil dari 0.05 yaitu sebesar 0.002 sehingga kesimpulan untuk hipotesis kedua $\mathrm{H} 4$ diterima dan H0 ditolak.

Bedasarkan hasil diatas temuan ini mendukung dan sejalan dengan hasil penelitian yang dilakukan oleh (Michael \& Rohman, 2017) dan (Riensky Dewangga Putra, Dr. Majidah, S.E., 2016) serta (Pham et al., 2014)yang menemukan adanya pengaruh yang siginifikan antara audit tenur dengan audit report lag. Lama masa jabatan KAP dan partner mempengaruhi audit report lag dikarenakan pemahaman atas karakteristik bisnis klien, dengan tenure yang panjang diharapkan memiliki pemahaman dan pengetahuan atas karakteristik bisnis industri perusahaan klien, sehingga dapat mengurangi potensi kegagalan audit dan meningkatkan efisiensi audit, yang kemudian menghasilkan audit report lag semakin pendek. Hasil penelitian menunjukan bahwa KAP dengan partner tenure selama lebih dari atau dibandingkan KAP dengan partner tenure kurang dari 3 tahun menandakan bahwa proses akumulasi pemahaman dan pengetahuan atas kondisi dan sistem akuntansi klien tidak berjalan dengan efektif dan progresif. Hal ini mungkin disebabkan bahwa KAP dengan partner tenure pendek, masih menilai bahwa dalam mengaudit laporan keuangan klien, auditor masih membutuhkan pembelajaran dalam beradaptasi dengan karakteristik bisnis dan sistem pencatatan klien, sehingga proses pemahaman dilakukan dengan optimal. Sedangkan KAP dengan partner yang memiliki tenure panjang diduga menilai bahwa KAP dengan partner tersebut telah memiliki pengetahuan yang cukup dihasilkan dari perikatan audit dengan klien yang sudah berjalan relatif lama. Sehingga bahwa dengan Tenure yang panjang akan mempengaruhi atau memperpendek Audit Report Lag dalam sebuah perusahaan, jadi perusahaan diaudit oleh KAP dengan partner auditor yang sama secara berturut turut hal akan mempengaruhi atau memperpendek Audit Report Lags dalam sebuah perusahaan. Namun hal ini berbeda menurut penelitian (Yogi et al., 2017), (Giyanto \& Rohman, 2019) serta (Gusti Ayu Dewi, 2017) yang menemukan tidak ada pengaruh yang siginifkan antara audit tenur dan audit report lag.

\subsection{Pengaruh Invesment Oportunity Set terhadap Audit Report Lag dan Peran Audit Spesialisasi Industri}

Hasil uji hipotesis kelima dapat dilihat pada tabel 4.8, variabel Invesment Oportunity Set mempunyai tingkat signifikansi sebesar 0.929 (pvalue $>0.05)$ dan koefiesien regresi dengan arah negatif sebesar -0.015 .

Hal ini dapat dikatakan bahwa hipotesis kelima diterima sehingga dapat dikatakan bahwa Invesment Oportunity Set tidak berpengaruh secara signifikan terhadap audit report lag karena tingkat siginifikansi yang dimiliki variabel investment opportunity set lebih besar dari 0.05 yaitu sebesar 0.929 sehingga kesimpulan untuk hipotesis kedua $\mathrm{H} 5$ diterima dan $\mathrm{H} 0$ ditolak.

Hasil diatas tidak sejalan dengan penelitian yang dilakukan oleh (Aninditia, 2016), (Cakra, 2017) dan (Pham et al., 2014) memberikan hasil bahwa ada pengaruh antara Invesment Opportunity Set terhadap audit report lag namun berbeda hasil 
penelitian ini sejalan dengan penelitian yang dilakukan oleh (Pramaharjan \& Cahyonowati, 2015)yang tidak menemukan adanya pengaruh Invesment Opportunity Set terhadap audit report Lag. Secara teori bahwa karena set kesempatan investasi yang tinggi ataupun rendah pada perusahaan tidak akan meningkatkan risiko audit sehingga auditor independen tidak harus memperluas ruang lingkup kerja audit agar dapat memetakan risiko audit dengan matang dalam rangka menentukan rencana kerja audit yang tepat.

Maka dari itu, dengan meningkat atau tidaknya risiko audit maka tidak mempengaruhi penyelesaian pemeriksaan auditor independen.

\subsection{Pengaruh Interkasi Auditor Spesialisasi industri dengan Ukuran Kantor Akuntan Publik, ROI, Ukuran Perusahaan, Audit Tenure dan IOS}

Bedasarkan hasil uji MRA (Moderate Analys Regresion) berikut penjelasan terkait dengan hipotesis keenam sampai kesepuluh.

Hasil uji hipotesis keenam dapat dilihat pada tabel 4.1 bahwa variabel ukuran KAP Mempunyai tingkat signifikansi sebesar 0.177 (p-value $>0.05$ ) dan koefiesien regresi dengan arah positif sebesar 0.338 dan variable moderasi dengan tingkat signifikansi sebesar 0.025 (p-value $<0.05$ ) hal ini dapat dikatakan bahwa hasil tersebut merupakan moderasi predictor dalam model hubungan yang di bentuk.

Hal ini dapat dikatakan bahwa hipotesis keenam ditolak sehingga dapat dikatakan bahwa peran dari auditor spesialisasi industry memperlemah hubungan antara ukuran KAP terhadap audit report lag karena tingkat siginifikansi yang dimiliki variabel ukuran KAP yang dimoderasi dengan auditor spesialisasi industry lebih besar dari 0.05 yaitu sebesar 0.177 sehinggan kesimpulan untuk hipotesis kedua H6 ditolak dan $\mathrm{H} 0$ diterima. Hal ini dapat memberikan penjelasan bahwa baik Kantor Akuntan Publik yang bereputasi baik berafiliasi dengan KAP the big four ataupun tidak berafiliasi dengan KAP the big four, tidak memberikan jaminan yang pasti bahwa dapat melakukan audit lebih cepat dan menyelesaikan auditnya sesuai jadwal sehingga informasi yang didapatkan lebih cepat diterima pengguna laporan keuangan didalam pengambilan keputusan.

Hasil penelitian hipotesis ini sejalan dengan penelitian Sinta dan Abdul (2017) serta Vinola dan Farhan (2019) yang memberikan hasil bahwa tidak ada pengaruh yang signifikan antara Ukuran KAP dengan audit report lag dan auditor spesialisasi industry tidak memoderasi hubungan keduanya, namun berbeda dengan hasil penelitian yang dilakukan (Pramaharjan \& Cahyonowati, 2015), (Arifa, 2013) yang menemukan ada pengaruh dari ukuran KAP terhadap audit report lag serta penelitian yang dilakukan oleh (Anggreni \& Latrini, 2016) yang menemukan audit spesialisasi industry memoderasi ukuran KAP terhadap audit report lag.

Selanjutnya Hasil uji hipotesis ketujuh dapat dilihat pada tabel 4.1, variabel Profitabilitas mempunyai tingkat signifikansi sebesar 0.010 (pvalue $<0.05$ ) dan koefiesien regresi dengan arah positif sebesar 0.695 dan variable moderasi dengan tingkat signifikansi sebesar 0.025 ( $\mathrm{p}$-value $<0.05$ ) hal ini dapat dikatakan bahwa hasil tersebut merupakan moderasi semu sehingga terdapat interaksi dalam model hubungan yang di bentuk dan sekaligus sebagai menjadi variable predictor.

Hal ini dapat dikatakan bahwa hipotesis ketujuh diterima sehingga dapat dikatakan bahwa peran dari auditor spesialisasi industry memperkuat hubungan antara profitbilitas terhadap audit report lag karena tingkat siginifikansi yang dimiliki variabel profitabilitas yang dimoderasi dengan auditor spesialisasi industry lebih besar dari 0.05 yaitu sebesar 0.010 sehinggan kesimpulan untuk hipotesis kedua $\mathrm{H} 7$ diterima dan $\mathrm{HO}$ diterima. Hal ini memberikan penjelasan bahwa ketika sebuah perusahaan menunjukan kerberhasilan perusahaan dalam menghasilkan keuntungan yang besar dan tingkat efektifitas keberhasilan tersebut dapat mempertimbangakan keputusan investasi karena akan memprediksi secara tepat untuk menghasilkan laba yang sangat baik sehingga akan meningkatkan tingkat pengembalian modal terhadap investor, sehingga hal ini dapat pula meningkatkan kesadaran terhadap pihak agent (manajemen perusahaan) dapat mempublikasikan laporan keuangan dan laporan auditor indpenden yang memeriksanya secara tepat waktu dan sesuai dengan peraturan yang telah di buat oleh pihak regulasi sehingga hal ini dapat menarik perhatian investor serta pengguna informasi keuangan untuk dapat mengambil keputusan dan kebijakan secara tepat dan benar.

Hasil penelitian hipotesis ini mendukung hasil penelitian yang dilakukan oleh (Nelson \& Shukeri, 2011), (Pramaharjan \& Cahyonowati, 2015) yang menemukan bahwa auditor spesialisasi industri memoderasi profitabilitas mempengaruhi audit report lag. Namun, hasil penelitian ini bertolak 
belakang dengan hasil penelitian (Tiono, 2013) dan (Fadoli, 2015) yang tidak menemukan auditor spesialisasi industri memoderasi pengaruh signifikan antara profitabilitas dengan audit report lag.

Selanjutnya Hasil uji hipotesis kedelapan dapat dilihat pada tabel 4.1, variabel Ukuran Perusahaan mempunyai tingkat signifikansi sebesar 0.038 (p-value < 0.05) dan koefiesien regresi dengan arah positif sebesar 2.169. dan variable moderasi dengan tingkat signifikansi sebesar 0.025 ( $\mathrm{p}$-value $<0.05$ ) hal ini dapat dikatakan bahwa hasil tersebut merupakan moderasi semu sehingga terdapat interaksi dalam model hubungan yang di bentuk dan sekaligus sebagai menjadi variable predictor.

Hal ini dapat dikatakan bahwa hipotesis kedelapan diterima sehingga dapat dikatakan bahwa peran dari auditor spesialisasi industry memperkuat hubungan antara profitbilitas terhadap audit report lag karena tingkat siginifikansi yang dimiliki variabel ukuran perusahaan yang dimoderasi dengan auditor spesialisasi industry lebih besar dari 0.05 yaitu sebesar 0.010 sehinggan kesimpulan untuk hipotesis kedua H8 diterima dan $\mathrm{H} 0$ ditolak. Semakin besar ukuran suatu perusahaan maka semakin rumit pula proses dalam melakukan auditnya namun dengan adanya auditor spesialisasi industry membuktikan bahwa dengan auditor yang mempunyai kompeten dalam bidang dan jenis industry tertentu dapat mempercepat dalam melakukan pemeriksaan walapun klien tersebut memiliki aset yang sangat besar sehingga laporan keungan yang telah diaudit oleh auditor indpenden dapat di informasikan dan disampaikan kepada para pengguana informasi secara tepat wakti. Selain itu terkait komponen dalam audit report lag, ukuran perusahaan mempengaruhi seluruh komponen baik scheduling, fieldwork, dan reporting lag.

Hasil penelitian ini mendukung hasil penelitian yang dilakukan oleh oleh (Pramaharjan \& Cahyonowati, 2015), (Tiono, 2013), (Riensky Dewangga Putra, Dr. Majidah, S.E., 2016)yang menemukan bahwa auditor spesialisisai industry memoderasi ukuran perusahaan mempengaruhi audit report lag. Namun, hasil penelitian ini bertolak belakang dengan hasil penelitian (Yogi et al., 2017)dan (Fadoli, 2015)yang tidak menemukan auditor spesialisasi industry memoderasi pengaruh signifikan antara ukuran perusahaan dengan audit report lag.
Selanjutnya Hasil uji hipotesis kesembilan dapat dilihat pada tabel 4.1, variabel Ukuran Perusahaan mempunyai tingkat signifikansi sebesar 0.046 (p-value < 0.05) dan koefiesien regresi dengan arah negatif sebesar -0.500 . dan variable moderasi dengan tingkat signifikansi sebesar 0.025 (p-value <0.05) hal ini dapat dikatakan bahwa hasil tersebut merupakan moderasi semu sehingga terdapat interaksi dalam model hubungan yang di bentuk dan sekaligus sebagai menjadi variable predictor.

Hal ini dapat dikatakan bahwa hipotesis kesembilan diterima sehingga dapat dikatakan bahwa peran dari auditor spesialisasi industry memperkuat hubungan antara audit tenur terhadap audit report lag karena tingkat siginifikansi yang dimiliki variabel audit tenur yang dimoderasi dengan auditor spesialisasi industry lebih besar dari 0.05 yaitu sebesar 0.046 sehinggan kesimpulan untuk hipotesis kedua $\mathrm{H} 9$ diterima dan HO ditolak. Hal ini menunjukkan bahwa dengan adanya spesialisasi industri auditor membuktikan audit report lag yang singkat dipengaruhi oleh tenure audit singkat maupun lama, kemudian Hasil penelitian ini juga mampu membuktikan keberlakuan teori kepatuhan (compliance theory) yang menjelaskan bahwa auditor akan mematuhi perikatan (katentuan-ketentuan) dikarenakan auditor menilai bahwa kewenangan tersebut mengatur perilaku auditor. Pemahaman terhadap katentuan-ketentuan yang berlaku akan bertambah seiring semakin lamanya KAP melakukan perikatan dengan klien, sehingga ketika semakin panjang audit tenure berdampak pada auditor yang akan lebih cepat dalam menyelesaikan proses audit sesuai surat perikatan yang telah disepakati yang berdampak pada audit report lag menjadi semakin pendek.

Hasil penelitian ini mendukung hasil penelitian yang dilakukan oleh (Anggreni \& Latrini, 2016), (Putu dan Gede, 2017) serta (Pham et al., 2014) yang menemukan bahwa auditor spesialisasi industri memoderasi audit tenur terhadap audit report lag. Kemudian hal ini tidak sejalan dengan penelitian yang dilakukan yang dilakukan (Gusti Ayu Dewi, 2017), (Makhabati \& Adiwibowo, 2019) serta (Giyanto \& Rohman, 2019)yang tidak menemukan bahwa auditor spesialisasi industry tidak memoderasi audit tenur terhadap audit report lag.

Selanjutnya Hasil uji hipotesis kesepuluh dapat dilihat pada tabel 4.1, variabel Ukuran Perusahaan mempunyai tingkat signifikansi sebesar 0.840 (p-value $>0.05)$ dan koefiesien 
regresi dengan arah negatif sebesar -0.036 . dan variable moderasi dengan tingkat signifikansi sebesar 0.025 (p-value $<0.05$ ) hal ini dapat dikatakan bahwa hasil tersebut merupakan moderasi predictor dalam model hubungan yang di bentuk.

Hal ini dapat dikatakan bahwa hipotesis kesepuluh ditolak sehingga dapat dikatakan bahwa peran dari auditor spesialisasi industry memperlemah hubungan antara investment opportunity set terhadap audit report lag karena tingkat siginifikansi yang dimiliki variabel audit tenur yang dimoderasi dengan auditor spesialisasi industry lebih besar dari 0.05 yaitu sebesar 0.840 sehinggan kesimpulan untuk hipotesis kedua H10 ditolak dan H0 diterima. Bahwa Secara teori set kesempatan investasi yang tinggi ataupun rendah pada perusahaan tidak akan meningkatkan risiko audit serta tidak mempengaruhi keahlian yang dimiliki oleh auditor dalam jenis industry apapun sehingga auditor independen tidak harus memperluas ruang lingkup kerja audit agar dapat memetakan risiko audit dengan matang dalam rangka menentukan rencana kerja audit yang tepat. Maka dari itu, dengan meningkat atau tidaknya risiko audit maka tidak mempengaruhi penyelesaian pemeriksaan auditor independen.

Hasil penelitian ini tidak mendukung hasil penelitian yang dilakukan oleh (Pham et al., 2014)yang menemukan bahwa auditor spesialisasi industry memoderasi investment oportuniy set terhadap audit report lag. Kemudian hal ini sejalan dengan penelitian yang dilakukan yang dilakukan (Pramaharjan \& Cahyonowati, 2015) yang tidak menemukan bahwa keterkaitan auditor spesialisasi industry dan investment opportunity set terhadap audit report lag.

\section{Kesimpulan, Keterbatasan dan Implikasi Hasil Penelitian}

Return on invesment dan ukuran perusahaan berpengaruh negatif terhadap audit report lag. Audit tenure berpengaruh positif terhadap audit report lag. Auditor spesialisasi industri sebagai variabel moderasi berpengaruh negatif terhadap audit report lag. Auditor spesialisasi industri memiliki peran sebagai pemoderasi pada pengaruh Return on invesment, ukuran perusahaan, dan Audit tenure terhadap audit report lag. Auditor spesialisasi industri tidak terbukti memiliki peran sebagai pemoderasi pada pengaruh ukuran kantor akuntan publik dan investment opportunity set terhadap audit report lag.
Kontribusi penting penelitian ini adalah bahwa ketepatwaktuan dipengaruhi oleh banyak factor Perusahaan yang tidak tepat waktu dalam menyampaikan laporan keuangan auditan kepada publik akan sangat merugikan perusahaan. Risiko keterlambatan adalah reaksi investor. Keterlambatan berdampak pada investor yang tidak berani mengambil resiko untuk berinvestasi diperusahaan.

Penelitian ini hanya menggunakan sampel perusahaan-perusahaan BUMN Go Public, sehingga hasil penelitian ini tingkat generalisasinya ren-dah. Periode penelitian yang digunakan terlalu pendek yang hanya menggunakan kurun waktu 5 tahun penelitian (2014-2018), sehingga tidak dapat mengukur indikasi audit report lag yang dilakukan oleh masing-masing perusahaan. Penelitian selanjutnya diharapkan menggunakan sampel yang lebih besar dari yang sudah pernah digunakan dalam penelitian ini atau sebelumnya dan menggunakan sampel perusahaan yang pesainnya banyak di setiap jenis industri.

\section{Daftar Pustaka}

Anggreni, N., \& Latrini, M. (2016). Pengaruh Audit Tenure Pada Kecepatan Publikasi Laporan Keuangan Auditan Dengan Spesialisasi Industri Auditor Sebagai Pemoderasi. E-Jurnal Akuntansi, 15(2), 13381365.

Aninditia. (2016). Pengaruh Invesment Oportunity Set dan Ukuran Perusahaan terhadap Audit report lag. Ekonomi Dan Bisnis UIN Syarif Hidayatullah Jakarta.

Arifa, A. N. (2013). Pengembangan Model Audit Delay Dengan Audit Report Lag Dan Total Lag. Accounting Analysis Journal, 2(2), 172181. https://doi.org/10.15294/aaj.v2i2.1441.

Bae, C. H., \& Woo, Y. S. (2015). The effect of audit report lag and management discretionary report lag on analyst forecasts: Evidence from Korea. Investment Management and Financial Innovations, 12(1), 319-333.

Cakra. (2017). Pengaruh Opini Audit, IOS dan Auditor Spesialisasi Industri terhadap Audit Report Lag. Ekonomi Dan Bisnis UIN Syarif Hidayatullah Jakarta. 
Dewi, I. C., dan Hadiprajitno, P. B. (2017). Pengaruh Audit Tenure dan Kantor Akuntan Publik (KAP) Spesialisasi Manufaktur terhadap Audit Report Lag. Diponegoro Journal of Accounting, 6(4), 1-12.

Fadoli, I. (2015). Pengaruh Faktor Internal Dan Eksternal Terhadap Audit Report Lag (Studi Empiris Pada Perusahaan Manufaktur dan Perbankan yang Terdaftar di BEI Tahun 20082013). Universitas Pandanaran, 1-15.

Ferdinan Giri, E. (2012). Akuntansi Keuangan Menengah 1, Edisi 1. In UPP STIM YKPN Yogyakarta.

Gaver, Jeniffer J., dan K. M. G. (1993). Additional Evidence on the Association between the Investment Opportunity Set and Corporate Financing, Dividen, and Compensation Policies. Journal Of Accounting \& Economics, $16,125-160$.

Giyanto, S. C., \& Rohman, A. (2019). Analisis Pengaruh Ukuran Kap, Tenure Kap Terhadap Audit Report Lag (Arl) Dengan Kap Spesialisasi Industri Sebagai Variabel Moderasi. Diponegoro Journal of Accounting, 7(4), 1-14.

Gusti Ayu Dewi, G. D. S. (2017). Pengaruh Kompleksitas Operasi, Kontinjensi, Pergantian Auditor pada Audit Report Lag dengan Spesialisasi Auditor sebagai Pemoderasi. E-Jurnal Akuntansi, 21, 912-941. https://doi.org/10.24843/EJA.2017.v21.i02.p0 2.

Habib, A., \& Bhuiyan, M. B. U. (2011). Audit firm industry specialization and the audit report lag. Journal of International Accounting, Auditing and Taxation, 20(1), 32-44. https://doi.org/10.1016/j.intaccaudtax.2010.12 .004 .

Haryani, J., \& Wiratmaja, I. D. N. (2014). Pengaruh Ukuran Perusahaan, Komite Audit, Penerapan Dan International Financial Reporting Standards Dan Kepemilikan Publik Pada Audit Delay. E-Jurnal Akuntansi Universitas Udayana, ISSN: 2302-8556, 6(1), 63-78.

Herawaty, V., \& Rusmawan, M. F. (2019). Pengaruh Audit Firm Status, Adit Complexity,
Kepemilikan Keluarga, Dan Loss Terhadap Audit Report Lag Dengan Spesialisasi Industri Sebagai Variabel Moderasi. Prosiding Seminar Nasional Pakar Ke 2 Tahun 2019, 2, 2.39.1-2.39.6.

Hesti. (2011). Analisis Faktor-faktor Yang Berpengaruh Terhadap Jangka Waktu Penyelesaian Audit (Kajian Empiris Pada Perusahaan Manufaktur Yang Terdaftar Di Bursa Efek Indonesia Tahun 2008-2009). http://ejournal.uajy.ac.id/14649/1/JURNAL.pdf.

IAI. (2009). Ikatan Akuntan Indonesia. Standar Akuntansi Keuangan,Salemba Empat, Jakarta, 2009.

Lianto, N, B. H. (2010). FAKTOR-FAKTOR YANG BERPENGARUH TERHADAP AUDIT REPORT LAG NOVICE LIANTO dan BUDI HARTONO KUSUMA. 12(2), 98-107.

Makhabati \& Adiwibowo. (2019). Pengaruh Reputasi Auditor Dan Spesialisasi Industri Auditor. 8(2017), 1-8.

Michael, C., \& Rohman, A. (2017). PENGARUH AUDIT TENURE DAN UKURAN KAP TERHADAP AUDIT REPORT LAG DENGAN SPESIALISASI INDUSTRI AUDITOR SEBAGAI VARIABEL MODERASI (Studi Empiris pada Perusahaan Manufaktur yang Terdaftar di Bursa Efek Indonesia tahun 20132015). 6(4), 378-389.

Nelson, S. P., \& Shukeri, S. N. (2011). Corporate governance and audit report timeliness: Evidence from Malaysia. In Research in Accounting in Emerging Economies (Vol. 11, Issue 1). Emerald Group Publishing Ltd. https://doi.org/10.1108/S14793563(2011)0000011010.

Oktaviani, S. (2017). Pengaruh Tenure Audit dan Listing Terhadap Audit Report Lag Dengan Spesialisasi Industri Auditor Sebagai variabel Moderating. JOM Fekon, 4(1).

Pham, T., Dao, M., \& Brown, V. L. (2014). Investment Opportunities and Audit Report Lags: Initial Evidence. Accounting and Finance Research, 3(4), 45-57. https://doi.org/10.5430/afr.v3n4p45. 
Pramaharjan, B., \& Cahyonowati, N. (2015). Faktor Faktor Yang Berpengaruh Terhadap Audit Report Lag Pada Perusahaan Manufaktur. Diponegoro Journal of Accounting, 4(4), 254048.

Pratiwi, L. A. dan Y. S. (2009). Faktor-Faktor yang Mempengaruhi Audit Report Lag (ARL). Solusi, 8(3), 29-41.

Putu dan Gede. (2017). Spesialisasi Auditor Sebagai Pemoderasi Pengaruh Audit Tenure Dan Ukuran Kap Pada Audit Report Lag. EJurnal Akuntansi, 18, 1230-1258.

Riensky Dewangga Putra, Dr. Majidah, S.E., M. S. . (2016). ANALISIS DETERMINASI AUDIT REPORT LAG. E-Proceeding of Management, $3(3), \quad 3233$. https://doi.org/10.7868/s0869565216210155.

Ross, A. S., Westerfield, R. W., Jordan, B. D., Lim, J., \& Tan, R. (2012). Fundamentals of Corporate Finance.

Sastrawan, I., \& Latrini, M. (2016). Pengaruh Profitabilitas, Solvabilitas, Dan Ukuran Perusahaan Terhadap Audit Report Lag Pada Perusahaan Manufaktur. E-Jurnal Akuntansi, 17(1), 311-337.
Simanjorang, R. M. (2018). Pengaruh Profitabilitas, Likuiditas, Solvabilitas, Dan Ukuran Perusahaan Terhadap Audit Report Lag Pada Perusahaan Yang Terdaftar Di Bursa Efek Indonesia. Jurnal Ilmiah Bisnis Dan Ekonomi Asia, 11(1), 64-70. https://doi.org/10.32812/jibeka.v11i1.34.

Sugiyarso, G., Winarni, F. (2005). Dasar - dasar Akuntansi Perkantoran. In Media Pressindo.

Tiono, I. dan Y. J. (2013). Faktor-Faktor yang Mempengaruhi Audit Report Lag di Bursa Efek Indonesia,. Business Accounting Review, II.

Yogi, M., Purnamasari, P., \& Maemunah, M. (2017). Pengaruh Ukuran Perusahaan dan Audit Tenure terhadap Audit Report Lag dengan Reputasi Kantor Akuntan Publik sebagai Variabel. Prosiding Akuntansi, 3 No 2, 370-374.

Yuliesti Rosalia, Kurnia, L. A. (2019). FAKTORFAKTOR YANG MEMPENGARUHI AUDIT REPORT LAG DENGAN REPUTASI KAP SEBAGAI PEMODERASI. SIKAP, 4(1), 44-57. 
Yudhi Prasetiyo, Nurmala Ahmar, M. Ardiansyah Syam : Determinan Audit Report Lag dan Peran Auditor Spesialisasi Industri Sebagai Pemoderasi Pada Perusahaan Badan Usaha ... 